\title{
PENGEMBANGAN MODEL PEMBELAJARAN BACA-TULIS PERMULAAN DALAM PERSPEKTIF EMERGENT LITERACY
}

\author{
Muakibatul Hasanah \\ Fakultas Sastra Universitas Negeri Malang \\ email: muakibatulhasanah@yahoo.co.id
}

\begin{abstract}
Abstrak
Penelitian ini bertujuan mengembangkan model pembelajaran baca-tulis permulaan untuk meningkatkan kompetensi baca-tulis siswa. Data penelitian berupa hasil kajian kurikulum pembelajaran baca-tulis permulaan, hasil survei pelaksanaan dan saran pembelajaran baca-tulis permulaan di SD, serta hasil uji prototipe model pembelajaran baca-tulis permulaan. Penelitian ini menghasilkan: (1) model panduan pembelajaran bacatulis permulaan yang dipilah atas hakikat baca-tulis permulaan dan strategi pembelajaran baca-tulis permulaan dalam perspektif emergent literacy dan (2) model majalah baca-tulis permulaan dengan standar performansi yang memiliki karakteristik bahasa, isi, dan tekniknya.
\end{abstract}

Kata kunci: baca-tulis permulaan, model pembelajaran, emergent literacy

\section{DEVELOPING A MODEL FOR THE LEARNING OF EARLY READING-WRITING IN THE EMERGENT LITERACY PERSPECTIVE}

\begin{abstract}
This study aims to develop a model for the learning of early reading-writing to improve students' reading-writing competencies. The research data were the results of a study of an early reading-writing curriculum, those of a survey on the implementation of and suggestions for the learning of early reading-writing at elementary schools, and those of a tryout of the prototype of a model for the learning of early reading-writing. The study produced: (1) a model of a guideline for the learning of early reading-writing divided into the essence of early reading-writing and strategies in the learning of early readingwriting in the emergent literacy perspective and (2) a model of an early reading-writing magazine using the performance standard with language characteristics, contents, and techniques.
\end{abstract}

Keywords: early reading-writing, learning model, emergent literacy

\section{PENDAHULUAN}

Salah satu usaha untuk mewujudkan visi pendidikan berwawasan keunggulan adalah dengan cara mengembangkan wawasan guru SD melalui pengembangan model pembelajaran baca tulis permulaan. Pengembangan model tersebut didasari pertimbangan bahwa baca-tulis permulaan merupakan kunci pembuka kompetensi yang lebih luas. Pengembangan wawasan bagi guru ini diharapkan akan berdampak positif bagi perkembangan kemampuan baca-tulis permulaan siswa.

Selain berdampak positif bagi pengembangan wawasan guru dan hasil belajar siswa, melalui model pembelajaran ini diharapkan dapat dihasilkan wawasan baru dan teori baca-tulis permulaan yang akan memperkaya khazanah teori pembelajaran baca-tulis permulaan. Pengembangan 
model pembelajaran baca-tulis permulaan dilandasi oleh hasil pengamatan yang menunjukkan bahwa tidak semua guru SD sanggup dan mampu mengajarkan baca-tulis permulaan di kelas. Pada umumnya para guru mengalami kesulitan mengajarkan baca-tulis permulaan. Kondisi yang demikian mengisyaratkan perlunya dilakukan pembinaan dan pengembangan wawasan agar mereka dapat menjadi guru yang profesional. Oleh karena itu, pengembangan model pembelajaran untuk memperkaya wawasan guru tentang baca-tulis permulaan dianggap merupakan usaha yang sangat tepat untuk dilaksanakan karena akan berdampak positif bagi pengembangan kompetensi baca-tulis siswa.

Kompetensi baca-tulis merupakan bagian dari kompetensi berbahasa. Kompetensi ini merupakan kompetensi dasar yang disajikan di semua level sekolah, mulai sekolah dasar sampai perguruan tinggi. Di jenjang sekolah dasar (SD) terutama di kelas awal, kompetensi tersebut dikenal sebagai kompetensi baca-tulis permulaan. Pengembangannya didasari akan pentingnya kompetensi tersebut sebagai prasyarat bagi pengembangan kompetensi yang lain.

Sebagai dasar penguasaan kompetensi yang lain, kompetensi baca-tulis permulaan diupayakan dapat dikuasai setiap siswa agar nantinya mereka menjadi manusia yang memiliki kualitas tinggi sehingga dapat memenuhi visi pendidikan yang berwawasan keunggulan. Hal tersebut sejalan dengan gagasan Rofi'uddin dan Zuhdi (1998) tentang perlunya dikembangkan visi pendidikan yang berwawasan keunggulan agar siswa mampu mengaktualisasikan segenap potensi yang ada secara maksimal dan berkelanjutan untuk meraih prestasi yang baik dari setiap aktivitas belajar di berbagai jenjang, jenis, dan jalur pendidikan.

Aktualisasi tersebut menyangkut aspek kognitif, psikomotor, dan afektif.
Kemampuan kognitif merujuk pada pengembangan kemampuan berpikir logis dan kreatif. Kemampuan berpikir logis ditandai oleh kemampuan berpikir sistematis, proporsional, probabilistik, dan korelasional; sedangkan kemampuan berpikir kreatif ditandai dengan kelancaran berpikir (fluency), keluwesan berpikir (fleksibel), keorisinalan berpikir, dan kerincian berpikir (elaboratif). Kemampuan psikomotorik ditandai oleh keterampilan dan daya tahan fisik yang prima dalam menyelesaikan tugas-tugas akademik. Sementara itu, kemampuan afektif ditandai oleh kemampuan seseorang mengembangkan perasaan dan emosinya secara lebih terkendali dan bertanggung jawab ke arah tercapainya keseimbangan antara rasio, indera, persepsi, imajinasi, dan karsa (Rofi'uddin dan Zuhdi, 1998).

Untuk menjadi manusia (siswa) yang berwawasan keunggulan sebagaimana dijelaskan di atas, pembelajaran di sekolah perlu didukung oleh pelaksana pendidikan (guru) yang unggul, termasuk guru-guru sekolah dasar di kelas awal. Mereka perlu dibekali pendidikan, baik yang menyangkut peningkatan penguasaan isi/materi maupun yang menyangkut peningkatan penyelenggaraan pembelajaran, termasuk pembelajaran baca-tulis permulaan.

Hasil wawancara dengan para guru SD menunjukkan bahwa tidak semua guru SD sanggup mengajar di kelas I dan para guru mengeluhkan sulitnya mengajarkan baca-tulis permulaan. Kondisi tersebut mengisyarakan perlunya pengembangan wawasan guru SD tentang pembelajaran baca-tulis permulaan. Kondisi tersebut di antaranya disebabkan terbatasnya buku-buku pembelajaran baca-tulis permulaan yang dapat mereka pelajari dan dapat digunakan sebagai rujukan dalam penyelenggaraan pembelajaran baca-tulis permulaan.

Keluhan yang senada juga muncul dari para siswa SD kelas awal (kelas I),

Pengembangan Model Pembelajaran Baca-Tulis Permulaan dalam Perspektif Emergent Literacy 
para siswa beranggapan bahwa belajar membaca dan menulis merupakan kegiatan yang sulit dan membosankan. Mereka umumnya merasa tertekan pada saat belajar baca-tulis permulaan karena tuntutan tujuan pembelajaran yang harus secepatnya mereka kuasai, yaitu dapat membaca dan menulis.

Salah satu yang diduga menjadi penyebabnya adalah perubahan cara belajar, cara belajar di SD tidak sama dengan cara belajar di taman kanak-kanak (TK). Pada saat masih di bangku TK, mereka dapat belajar sambil bermain dan bermain seraya belajar - sejalan dengan Kurikulum TK tentang pelaksanaan pembelajaran di TK. Akan tetapi, saat mereka memasuki jenjang SD, cara belajar sambil bermain sudah tidak lagi mereka dapatkan. Kondisi inilah yang membuat anak-anak SD kelas awal mengeluh dalam belajar. Oleh karena itu, melalui pengembangan model pembelajaran baca-tulis permulaan, hasil penelitian ini diharapkan dapat memberikan wawasan kepada guru SD tentang pembelajaran baca-tulis permulaan agar siswa SD kelas awal dapat belajar dengan baik disertai perasaan senang. Pengembangan wawasan guru tentang pembelajaran baca-tulis permulaan dapat memahamkan guru akan hakikat bacatulis permulaan yang benar dan strategi pembelajaran baca-tulis permulaan yang menarik.

Perdebatan tentang kapan sebenarnya seorang anak mulai mengenal bacatulis menurut Cox (1999) berawal pada dekade 60-an, tepatnya sejak para periset meneliti anak-anak yang dapat membaca dan menulis permulaan secara alami. Temuan mereka menunjukkan bahwa pengenalan baca-tulis tidaklah dimulai pada usia tertentu, tetapi muncul secara berkesinambungan. Perkembangan baca-tulis dimulai dengan pengalaman pertama anak dalam mengenal cetak tulis (print) di rumah dan berlanjut ketika anak memasuki prasekolah serta tahun- tahun pertama saat duduk di SD. Temuan tersebut mengubah perspektif tentang baca-tulis permulaan sehingga baca-tulis permulaan didefinisikan sebagai perilaku awal baca-tulis anak yang berkembang ke pengenalan wacana, yang dikenal dengan istilah emergent literacy.

Berdasarkan temuan penelitian tentang pembaca pemula yang alami, Cox (1999) menegaskan bahwa anak-anak memulai belajar membaca sejak sebelum mereka memasuki pendidikan formal di SD. Pengalaman yang berhubungan dengan lingkungan cetak tulis dan pengalaman dengan buku cerita yang dibawa dari rumah dan prasekolah merupakan faktor-faktor signifikan dalam membaca permulaan.

Lingkungan yang kaya akan cetak tulis merupakan sumber belajar membaca permulaan. Anak-anak dapat memahami konsep dan kata yang kompleks. Misalnya kata-kata yang berhubungan dengan makanan, minuman, mainan, dan cerita kartun dalam lingkungan yang bermakna karena kata-kata tersebut tersajikan dalam konteks penuh makna (meaningfull).

Selain lingkungan yang kaya akan tulisan, pengalaman dengan buku cerita mendorong anak untuk mulai belajar membaca. Melalui kegiatan membacakan cerita atau membicarakan isi cerita dengan anak yang dilakukan oleh orang dewasa, anak akan meniru beberapa perilaku membaca, seperti: membuka halaman, memegang atau melihat buku, menyentuh halaman, menceritakan kembali isi cerita, dan menggunakan bahasa buku.

Anak-anak akan mulai bereksperimen dengan bahasa tulis jika diberi bahan dan kesempatan menulis atau jika didampingi orang dewasa yang bertindak sebagai model yang akan diikutinya. Eksperimen tersebut secara bertahap akan berkembang ke arah tulisan konvensional.

Tahap-tahap perkembangan menulis permulaan secara rinci dideskripsikan oleh Sulzby (1989) dengan memerikan 
bentuk-bentuk tulisan anak. Perkembangan bentuk-bentuk yang dimaksud meliputi: membuat tanda (scribbling), menggambar, membuat huruf nonfonetik, menulis ejaan temuan, dan menulis secara konvensional.

Untuk sampai pada kemampuan menulis secara konvensional, anak-anak berusaha memahami dan menguasai prinsipprinsip bahasa tulis (Cox, 1999). Dengan kata lain, anak-anak menemukan konsep tentang tulisan yang ditandai dengan prinsip-prinsip: (1) prinsip tanda dan pesan, (2) prinsip fleksibilitas, (3) prinsip perulangan, (4) prinsip perampatan, (5) prinsip kontras, dan (6) prinsip arah, spasi, dan halaman.

Perkembangan cara anak menulis menghasilkan ejaan temuan anak-anak yang mengikuti lima tahap: tahap penyimpangan, tahap prafonetik, tahap fonetik, tahap transisional, dan tahap benar. Tahapan tersebut diuraikan berikut ini.

Pertama, tahap penyimpangan: anakanak menyadari bahwa ujaran dapat direkam dengan simbol-simbol grafis, pada tahap ini anak menghasilkan gambar yang secara bertahap berubah menjadi huruf atau angka. Tahap ini berlangsung pada usia prasekolah.

Kedua, tahap prafonetik: anak-anak dapat mengeja kata-kata tetapi belum memahami benar konsep tentang kata, anak tahu nama huruf dan menulis satu, dua, atau tiga huruf sebagai representasi kata tunggal. Tahap ini berlangsung pada saat taman kanak-kanak sampai awal kelas 1 SD (5-6 tahun).

Ketiga, tahap fonetik: anak-anak dapat mengeja keseluruhan bunyi dalam satuan kata yang didengarnya dan menuliskannya sebagaimana bunyi yang didengarnya sehingga tulisan yang dihasilkannya berciri fonetik, bukan fonemik. Tahap ini berlangsung antara kelas 1-3 SD (6-8 tahun).

Keempat, tahap transisional: anakanak menggunakan huruf vokal pada semua suku kata serta menggunakan pola-pola yang dikenal. Tahap ini berlangsung pada akhir kelas 1 sampai awal kelas 2 SD (7-8 tahun).

Kelima, tahap benar: anak-anak menghasilkan tulisan tentang kata dengan ejaan yang benar, sekalipun masih bermasalah dengan kata berimbuhan dan berkonsonan ganda. Tahap ini berlangsung antara kelas 2-4 SD (7-9 tahun).

\section{METODE}

Penelitian ini bertujuan mengembangkan model pembelajaran untuk guru SD tentang baca-tulis permulaan beserta perangkat pendukungnya. Sejalan dengan tujuan tersebut, maka desain penelitian yang digunakan adalah desain penelitian pengembangan. Desain penelitian pengembangan dirancang untuk menghasilkan produk yang berupa model pembelajaran dan perangkat pendukungnya.

Sesuai dengan desain penelitian yang digunakan, pengembangan model dilaksanakan dengan prosedur: pengkajian teori, survei, pengembangan model, uji model, dan revisi model (Suyanto, 2005; Setyosari, 2013). Pengkajian teori dilakukan untuk memperoleh dasardasar berpijak dalam mengembangkan model. Teori-teori yang dimanfaatkan dan dikaji mencakup teori: (1) perkembangan bahasa dan pembelajarannya, (2) bacatulis permulaan dan pembelajarannya, (3) pendekatan pembelajaran bahasa, (4) psikologi anak usia SD kelas awal, dan (5) teori permainan.

Survei dilakukan terhadap model pembelajaran baca-tulis permulaan di SD, kurikulum SD, dan pelaksanaan pembelajaran di SD. Selain itu, dilakukan pula survei untuk memetakan kebutuhan dan saran dari para guru SD terkait dan saran dari para pakar pendidikan terkait pembelakaran baca-tulis permulaan.

Data hasil pengkajian teori dan data hasil survei dari guru SD digunakan sebagai dasar pengembangan prototipe model

Pengembangan Model Pembelajaran Baca-Tulis Permulaan dalam Perspektif Emergent Literacy 
pembelajaran dan perangkat pendukungnya. Prototipe model pembelajaran beserta perangkat pendukungnya yang sudah dikembangkan diuji secara terbatas untuk melihat kelayakannya secara teoretis dan metodologis bagi guru dan siswa SD.

Data penelitian tersebut dikumpulkan dengan instrumen penelitian berupa instrumen tabel identifikasi data kajian teori, angket atau kuesioner untuk guru SD kelas I, dan instrumen pengumpul data saran ahli pendidikan. Untuk menjamin keabsahan data yang terkumpul dilakukan uji keabsahan data dengan teknik identifikasi data secara berulang-ulang dan identifikasi oleh dua peneliti. Dengan cara demikian, diharapkan validitas internal data akan terjamin keabsahannya.

\section{HASIL DAN PEMBAHASAN \\ Hasil Eksplorasi Pembelajaran Baca- Tulis Permulaan \\ Kurikulum SD Mata Pelajaran Bahasa Indonesia}

Temuan hasil eksplorasi kurikulum SD mencakup: (a) isi komponen latar belakang yang mendasari disusunnya standar kompetensi mata pelajaran, (b) komponen tujuan yang meliputi standar kompetensi dan kompetensi dasar. Isi komponen latar belakang yang mendasari disusunnya standar kompetensi mata pelajaran secara filosofis mengakomodasi gagasangagasan mutakhir tentang peran bahasa bagi perkembangan siswa. Isi komponen juga mewadahi kebutuhan akan bahasa Indonesia sebagai alat berkomunikasi serta penghargaan terhadap karya sastra Indonesia. Harapan yang mendasari penyusunan standar kompetensi pada tataran ideasi sangat berterima sekalipun dalam aplikasi di lapangan jauh dari harapan mengingat kesiapan sekolah, guru, dan daerah yang beraneka ragam.

Komponen tujuan kurikulum secara umum tidak mengalami perubahan jika dibandingkan Kurikulum 1994 dengan Kurikulum Berbasis Kompetensi (KBK).
Hal ini dimungkinkan karena keenam rumusan tujuan kurikulum mengacu pada taksonomi ranah kognitif, afektif, dan psikomotorik model Bloom. Bahkan ranah afektif mendapatkan porsi cukup besar. Tiga dari enam tujuan menuansakan ranah afektif, sedangkan tiga tujuan yang lain memberat ke ranah kognitif, sedangkan tiga tujuan yang lain memberat ke ranah psikomotorik (keterampilan berbahasa) yang juga tampak pada komponen ruang lingkup.

Komposisi tujuan yang demikian ternyata tidak secara konsisten diwujudkan dalam rumusan komponen standar kompetensi dan kompetensi dasar terutama untuk kelas I. Standar kompetensi untuk kelas 1 pada semester 1 dan 2 semata-mata diorientasikan pada ranah keterampilan, yakni mendengarkan, berbicara, membaca, dan menulis. Tidak satu pun yang berorientasi pada ranah afektif, yakni apreasiasi bahasa dan apreasiasi sastra. Komponen kompetensi dasar sedikit berbeda. Dari 24 paparan butir kompetensi dasar, 7 kompetensi dasar di antaranya berorientasi ke ranah afektif, selebihnya memberat ke ranah keterampilan.

Hal demikian jelas menunjukkan pengabaian aspek sikap yang seharusnya menda-patkan perhatian dalam penyusunan kompetensi dasar. Di lapangan pada penyelenggaraan pembelajaran sangat mungkin guru atau sekolah lebih berfokus pada isi kompetensi dasar yang terjabar dalam kurikulum, jarang yang mengacu ke tujuan kurikulum.

\section{Pelaksanaan Pembelajaran Baca-Tulis Permulaan}

Berdasarkan analisis data pelaksanaan pembelajaran baca-tulis permulaan yang dilakukan guru, ditemukan perian tentang pembelajaran baca-tulis permulaan berikut. Pertama, guru umumnya melaksanakan pembelajaran baca-tulis permulaan dengan strategi konvensional yakni hanya melatih baca tulis yang ber- 
langsung secara mekanis. Kedua, guru umumnya memfokuskan pembelajaran menulis permulaan untuk pengembangan kompetensi mekanis seperti menyalin, menebak, membuat kalimat. Ketiga, guru umumnya memfokuskan pembelajaran membaca permulaan dengan melatih melafalkan kata. Guru tidak mengembangkan aspek afektif, yakni minat dan motivasi anak agar anak: senang belajar membaca, senang belajar menulis, dan senang memanfaatkan pengetahuan untuk memprediksi kata berikutnya. Keempat, guru umumnya menggunakan buku pelajaran Bahasa Indonesia dan buku cerita sebagai sumber belajar tetapi sedikit yang menggunakan permainan. Kelima, guru umumnya menggunakan model pembelajaran yang monoton. Strategi pembelajaran kurang motivasional. Keenam, guru menggunakan evaluasi proses yang dilaksanakan selama pembelajaran tetapi hanya untuk mengukur kompetensi menyalin dan menjawab pertanyaan bacaan.

Kegiatan pembelajaran yang demikian menunjukkan bahwa guru masih cenderung melakukan atau menerapkan model pembelajaran membaca kata secara lepas. Kenyataan tersebut berbeda dari pandangan "whole language" yang menyarankan agar pembelajaran baca-tulis permulaan dilaksanakan dalam konteks bermakna, setidaknya dalam konteks kalimat atau wacana pendek. Demikian pula dengan kegiatan pembelajaran menulis, dengan aktivitas belajar menyalin, menebali, melengkapi kata juga menunjukkan bahwa pembelajaran menulis lebih bersifat melatih kemampuan motorik halus dan berfokus pada kata. Hal tersebut jelas membuat pembelajaran baca-tulis permulaan menjadi kurang bermakna.

Bahan pembelajaran yang berupa kata-kata pada umumnya bersumber dari buku pelajaran. Dengan demikian, guru mengikuti apa yang tersajikan dalam buku. Jika buku pelajaran disusun de- ngan didasari teori baca-tulis permulaan yang konvensional, maka jelas guru akan menggunakan bahan yang juga konvensional.

Teknik evaluasi yang digunakan guru sebagian besar berupa pengamatan. Hal tersebut tidak sejalan dengan pelaksanaan evaluasi selama proses pembelajaran baca-tulis permulaan. Adapun bentuk tes yang digunakan menunjukkan hal yang berbeda dengan kegiatan pembelajaran. Dilihat dari pandangan whole language, evaluasi pembelajaran baca-tulis permulaan seharusnya dilakukan dalam konteks bermakna. Kenyataan tersebut menunjukkan pemahaman guru akan pembelajaran baca-tulis permulaan yang bermakna tidak utuh. Praktik pembelajaran yang demikian menunjukkan bahwa kebutuhan guru akan model bahan pembelajaran baca-tulis permulaan dirasa lebih mendesak.

\section{Saran Guru SD tentang Pembelajaran Baca-Tulis Permulaan}

Berdasarkan hasil analisis atas saran guru tentang model pembelajaran berkenaan dengan komponen pembelajaran baca-tulis permulaan ditemukan hal-hal yang paralel dengan konsep baru tentang baca-tulis permulaan. Hal-hal yang dimaksud terurai sebagai berikut.

Bahan pembelajaran baca-tulis permulaan yang disarankan guru di antaranya memiliki karakteristik: menarik, menantang sesuai dengan karakter anak, dan mengikuti perkembangan anak. Karakteristik yang demikian sejalan dengan konsep baca-tulis permulaan yang mutakhir, terutama yang mengacu pada sifat alami pengenalan baca-tulis permulaan yang lebih bermakna. Karakteristik tersebut menjadi lebih mungkin terwujud jika bahan pembelajaran dikemas dalam bentuk permainan (sebagaimana disarankan guru) karena permainan membuat anak lebih tertarik dan tertantang untuk belajar baca-tulis (Hasanah, 2006, 2012). 
Strategi pembelajaran baca-tulis permulaan yang disarankan guru di antaranya memiliki karakteristik: variatif, menarik minat berupa permainan, terpadu dengan kegiatan berbahasa lisan, terpadu dengan pelajaran lain, dan sesuai dengan kebutuhan anak. Saran yang demikian bertolak dari harapan guru SD akan tersedianya panduan strategi pelaksanaan pembelajaran baca-tulis permulaan yang berkarakteristik sebagaimana terdeskripsikan. Dengan kata lain, guru membutuhkan panduan pelaksanaan pembelajaran baca-tulis permulaan yang ideal.

Media pembelajaran baca-tulis permulaan yang disarankan guru di antaranya memiliki karakteristik: variatif, berupa permainan, menarik (berwarna dan inovatif), murah biaya pembuatannya dan mudah digunakan. Sebagaimana saran tentang strategi, saran tentang media baca-tulis permulaan bertolak dari harapan guru SD akan tersedianya media pembelajaran baca-tulis permulaan yang ideal. Guru memahami bahwa media pembelajaran baca-tulis permulaan harus berkarakteristik lingkungan, tetapi guru belum menguasai cara membuat atau menemukan media sebagaimana diharapkan.

Alat evaluasi pembelajaran baca-tulis permulaan yang disarankan guru adalah alat evaluasi proses yang memanfaatkan gambar yang kaya sehingga dapat digunakan sebagai instrumen pengukur ranah afektif dan psikomotor. Saran akan evaluasi pembelajaran baca-tulis permulaan menggambarkan pemahaman guru akan bentuk alat evaluasi yang ideal dipandang dari sudut psikologi pembelajaran. Hanya saja pemahaman tersebut tidak linier dengan kegiatan pembelajaran baca-tulis permulaan yang dilaksanakan guru di kelas.

\section{Hasil Uji Terbatas Prototipe Model Pem- belajaran \\ Hasil Uji Prototipe Panduan Pembelaja- ran Baca-Tulis Permulaan}

Prototipe panduan pembelajaran baca-tulis permulaan dipilah atas: (1) hakikat baca-tulis permulaan dan (2) strategi pembelajaran baca-tulis permulaan dalam perspektif emergent literacy. Panduan tersebut diharapkan akan memperkaya wawasan guru tentang baca-tulis permulaan di SD.

Wawasan tentang hakikat baca-tulis permulaan yang mutakhir perlu diberikan kepada guru SD kelas I agar para guru memahami akan konsep yang diyakini kebenarannya oleh para ahli pembelajaran baca-tulis permulaan. Pemahaman secara benar tentang hakikat baca-tulis permulaan akan menjadi dasar bagi guru dalam melihat siswa beserta potensi kebahasaan yang sudah dimiliki siswa. Dari pemahaman tersebut guru diharapkan akan lebih kritis dan kreatif dalam merancang pembelajaran baca-tulis permulaan.

Wawasan terkait hakikat baca-tulis permulaan berisikan uraian teoretis yang disarikan dari kajian teori dan temuan penelitian tentang baca-tulis permulaan yang berkembang selama ini. Konsep lama tentang baca-tulis permulaan mengatakan bahwa baca-tulis permulaan secara formal boleh diajarkan setelah anak melewati masa kesiapan membaca (reading readiness), yakni setelah anak mencapai usia 6 tahun. Konsep baca-tulis permulaan yang baru berkeyakinan bahwa baca-tulis permulaan sudah dimulai sejak anak mengenal tulisan jauh sebelum anak memasuki sekolah. Pengenalan tersebut berlangsung dalam konteks kehidupan sehari-hari yang bersifat alami. Oleh karena itu, tidaklah dilarang untuk mengenalkan baca-tulis permulaan sebelum usia 6 tahun asalkan penyajiannya dikemas dalam bentuk kegiatan yang meniru proses pemerolehan baca-tulis permulaan di luar kelas yang bersifat alami. 
Wawasan tentang membaca permulaan berguna bagi pemahaman guru terhadap perilaku membaca permulaan yang alami. Dengan demikian, guru diharapkan mulai memikirkan cara-cara yang efektif untuk membentuk perilaku membaca permulaan siswa, sebagai alternatif dari cara-cara yang selama ini diterapkan oleh guru. Cara-cara yang dimaksud adalah memajani siswa dengan buku-buku dan barang cetak tulis lain. Selain itu, guru diharapkan dapat menciptakan situasi pembelajaran baca-tulis permulaan yang kondusif serta mendekati situasi yang dipaparkan.

Wawasan tentang menulis permulaan berguna bagi pemahaman guru tentang tahap-tahap menulis permulaan. Dengan pemahaman tersebut, guru diharapkan lebih toleran terhadap perkembangan tulisan setiap individu siswa sebelum siswa sampai pada penguasaan bentuk tulisan yang konvensional. Pemahaman terhadap proses tersebut diharapkan akan mendorong guru untuk menciptakan kegiatan menulis yang lebih kreatif dan bermakna bagi siswa dibanding kegiatan yang sekadar melatih siswa untuk menulis dengan tulisan yang rapi.

Wawasan tentang pembelajaran bacatulis permulaan meliputi paparan: teori baca-tulis permulaan, kompetensi bacatulis permulaan, tujuan pembelajaran baca-tulis permulaan, kegiatan pembelajaran baca-tulis permulaan, dan strategi pembelajaran baca-tulis permulaan. Paparan teori pembelajaran baca-tulis permulaan berguna bagi guru untuk mengembangkan pendekatan pembelajaran baca-tulis permulaan ke dalam langkah-langkah operasional di kelas. Pendekatan yang dimaksud bertolak dari konsep whole language.

Paparan kompetensi baca-tulis permulaan dalam panduan pembelajaran bacatulis permulaan meliputi tujuan, standar kompetensi, dan kompetensi dasar. Paparan teori pembelajaran baca-tulis per- mulaan berisi uraian tentang bagaimana anak belajar baca-tulis permulaan di luar kelas, yakni dengan meniru orang lain, mencoba berekspresi dengan baca-tulis serta memiliki kecepatan belajar baca-tulis permulaan yang berbeda-beda.

Spodek (1994) menggunakan prinsip yang dikembangkan dari teori pembelajaran bahasa sebagai berikut: (a) pada dasarnya anak memiliki fasilitas alami untuk belajar bahasa; (b) membaca dan menulis merupakan perluasan pengembangan bahasa lisan; (c) belajar berbicara, menyimak, membaca, dan menulis akan terkuasai dengan sangat baik bila dilakukan secara terpadu.; (d) anak akan belajar bahasa secara alami jika kompetensi dan kemampuan bahasa anak tetap terjaga; (e) lingkungan belajar hendaknya memberi berbagai kesempatan untuk menggunakan bahasa lisan dan tulis; (f) bahasa dan belajar bahasa sebaiknya dirancang dalam aktivitas yang mendorong terjadinya diskusi dan berbagi pendapat; (g) anak-anak perlu diberi pilihan materi dan aktivitas belajar; (h) guru mengembangkan lingkungan belajar mendorong dan mengarahkan anak untuk belajar sendiri; dan (i) pembelajaran bahasa harus kontekstual, kecuali jika anak membutuhkan keterampilan tertentu.

Salah satu hasil penelitian Goodman (via Routman, 1994) yang mendukung prinsip-prinsip tersebut adalah temuannya tentang apa yang dilakukan anakanak kelas 1-3 dalam proses membaca. Dia menemukan bahwa ketika siswa diminta membaca cerita yang utuh, mereka dapat membaca kata dalam konteks yang semula tidak terbaca di luar konteks. Mereka berusaha menerjemahkan tulisan dan berusaha menemukan makna. Temuan tersebut menunjukkan bahwa siswa akan lebih mudah memahami pesan dalam konteks wacana yang utuh dan autentik. Wacana yang autentik akan lebih mudah ditemukan jika anak di"cemplung"kan pada beragam wacana berkonteks ala-

Pengembangan Model Pembelajaran Baca-Tulis Permulaan dalam Perspektif Emergent Literacy 
miah dan sosial. Kemudahan tersebut juga akan terbentuk dengan lebih baik jika konteks sosial di kelas dan di rumah turut diperhitungkan dalam pengembangan kemampuan baca-tulis permulaan bagi siswa Kelas 1 SD.

Tujuan pembelajaran baca-tulis permulaan secara umum adalah untuk memotivasi atau mengembangkan minat, kesenangan, dan kebiasaan menulis pada diri siswa. Hal tersebut dianggap lebih mendasar daripada sekadar memberikan keterampilan mekanis, seperti: menebali, menjiplak atau menyalin.

Terkait dengan wawasan strategi pembelajaran baca-tulis permulaan, Cox (1999) memberikan paparan kegiatan umum yang bisa dilakukan oleh guru. Kegiatan umum yang dimaksud berkaitan dengan penataan kelas, penciptaan lingkungan kaya tulisan atau menciptakan pojok kegiatan. Kegiatan umum lainnya yang dapat dilakukan secara rutin meliputi kegiatan meluangkan waktu berbagi dan membaca nyaring. Selain itu, kegiatan umum yang bisa dilakukan adalah bermain drama serta menulis dan menggambar sebagai sarana bagi siswa untuk berekspresi dan bereksperimen atau bermain-main dengan bahasa.

Selain strategi yang ditawarkan Cox, strategi pembelajaran berikut merupakan alternatif strategi pembelajaran baca-tulis yang dapat digunakan. Strategi yang dimaksud dikembangakan dari pendekatan permainan berbahasa yang meliputi: tekateki silang, klos bergambar, membaca dan menuliskan gambar, menebak nama, mencari jejak, menggambar/mewarnai sesuai isi teks, memasang gambar dan teks, melanjutkan cerita, menulis bisikan teman, menulis dramatisasi kelompok, mendeskripsikan teman, dan menebak benda misteri.

\section{Hasil Uji Prototipe Majalah Baca-Tulis Permulaan}

Majalah anak merupakan salah satu media pembelajaran yang sering dimanfaatkan dalam proses pembelajaran di TK tetapi tidak di SD. Di SD peran majalah digantikan oleh buku pelajaran atau LKS (lembar kegiatan siswa). Padahal, majalah memiliki kelebihan dibandingkan buku pelajaran atau LKS. Majalah memiliki format dan ilustrasi gambar yang relatif lebih kaya dibandingkan buku pelajaran atau LKS. Oleh karena itu, majalah relatif lebih disukai siswa dibandingkan buku pelajaran atau LKS (Nurchasanah, 2004, 2005). Atas dasar itulah, dikembangkan model majalah baca-tulis permulaan.

Sebagai majalah anak, prototipe majalah baca-tulis permulaan dikembangkan dengan standar performansinya yang memiliki karakteristik yang berbeda, baik dari aspek bahasa, isi, maupun tekniknya. Dari aspek bahasa, majalah baca-tulis permulaan memiliki ciri: (1) kosakata yang digunakan sesuai dengan kemampuan anak, (2) kalimatnya pendek-pendek, bukan kalimat kompleks, (3) gaya penyajian menggunakan gaya bahasa komunikatif. Dari aspek isi, majalah baca-tulis permulaan disusun dengan memperhatikan program kegiatan di SD dalam mewujudkan tujuan pendidikan nasional. Dari aspek teknik, dalam majalah baca-tulis permulaan digunakan permainan sebagai sarana pembelajaran, dilengkapi gambar yang berwarna-warni, dan interaksi pembelajarannya dirancang dengan berbagai model variatif yang disesuaikan dengan perkembangan psikologi anak.

Dasar pengembangan majalah bacatulis permulaan berkaitan dengan masalah: (1) pendekatan pembelajaran majalah anak, (2) model pembelajaran dalam majalah anak, (3) kebijakan kurikulum: tujuan, materi, tema, dan sebagainya; serta (4) saran dari guru SD. Masing-masing dideskripsikan berikut ini. Terkait dengan pendekatan pembelajaran, beberapa 
pendekatan yang dipakai sebagai dasar pengembangan model adalah pendekatan toleransi budaya, permainan, global, integratif, Krashen i+1, dan repetisi. Pendekatan toleransi budaya memiliki ciri: (1) memperhatikan variasi budaya yang ada, (2) memperhatikan budaya yang secara umum dikenal anak, dan (3) budaya yang berada di lingkungan anak.

Pendekatan permainan memiliki ciri: (1) mementingkan proses belajar, bukan hasil, (2) ada aturan bermain, (3) bersifat menyenangkan, dan (4) memberikan kebebasan menentukan pilihan, sebagaimana disarankan oleh Johnson, Christie, dan Yawsky (1997). Ciri-ciri yang melekat pada permainan memungkinkan orang tua, guru, dan masyarakat pada umumnya sering menggunakan permainan sebagai sarana untuk mengembangkan pengetahuan, keterampilan berbahasa, perasaan sosial, dan mental anak.

Permainan secara psikologis memang diperlukan bagi perkembangan anak. Berdasarkan teori relaksasi, van Horn dkk. (1993) menjelaskan bahwa permainan digunakan sebagai sarana rehat untuk mengisi energi yang terkuras sehabis melakukan aktivitas. Terkait dengan teori konstruktivisme Vygotsky, van Horn dkk. (1993) juga mengatakan bahwa permainan merupakan kreasi situasi imajinatif yang menjembatani anak dengan dunia luar (masyarakat). Melalui permainan, anak dapat belajar mengatasi kesulitan yang dihadapinya.

Dari aspek linguistik, pendekatan yang digunakan adalah pendekatan global. Pendekatan ini memiliki ciri mengajarkan bahasa secara utuh dan bukan mengajarkan satuan-satuan bahasa. Namun demikian, untuk menghindari sifat menghafal pada diri anak, bahasa yang utuh itu dianalisis dan disintesis. Selain itu, pembelajaran juga didasari pendekatan tersebut diadasar konsep bahasa terpadu (whole language) yaitu sebuah pendekatan yang memandang membaca, menulis, berbicara, dan menyimak sebagai bagian dari keutuhan yang terpadu. Karenanya, bahasa harus diajarkan dalam cara yang terpadu pula sebagaimana pendapat Searfoss dan Readence (1994:117), "whole language is really a perspective about how language is acquired and used." Akan tetapi, Rubin (1995:13) menawarkan sebuah pendekatan sebagai modifikasi dari bahasa terpadu, yaitu pendekatan yang memadukan bahasa terpadu dengan perkembangan kemampuan sikuensial. Pendekatan yang dimaksud melibatkan bentuk pembelajaran langsung, pengelompokan yang fleksibel, pembelajaran gramatika, dan penggunaan beragam bahan. Pendekatan tersebut merupakan suatu keseimbangan, suatu campuran yang memadukan semua keterampilan berbahasa.

\section{SIMPULAN}

Pengembangan model pembelajaran baca-tulis permulaan bertujuan memperkaya wawasan guru SD tentang pembelajaran baca-tulis permulaan sehingga dapat meningkatkan kompetensi baca-tulis siswa kelas 1. Pengembangan model tersebut yang meliputi panduan pembelajaran baca-tulis permulaan dan majalah bacatulis permulaan diawali dengan survei terhadap teori pembelajaran baca-tulis permulaan, kurikulum SD, dan pelaksanaan pembelajaran baca-tulis permulaan yang dilengkapi dengan saran dari guru SD dan pakar pendidikan. Penelitian menghasilkan: (1) panduan pembelajaran baca-tulis permulaan dipilah atas hakikat baca-tulis permulaan dan strategi pembelajaran baca-tulis permulaan dalam perspektif emergent literacy; dan (2) majalah baca-tulis permulaan dengan standar performansinya yang memiliki karakteristik yang berbeda, baik dari aspek bahasa, isi, maupun tekniknya. 


\section{UCAPAN TERIMA KASIH}

Ucapan terima kasih disampaikan kepada Direktur DP2M Dikti yang telah mendanai penelitian ini. Ucapan terima kasih juga disampaikan kepada Ketua LP2M UM yang telah memfasilitasi penelitian ini.

\section{DAFTAR PUSTAKA}

Cambourne, B. 1994. How Important is Theory to Reading Teacher? Australian Journal of Reading. 2:78-90.

Cox, C. 1999. Teaching Language Arts: A Student and Response-Centered Classroom. Boston: Allyn and Bacon.

Depdikbud. 1994. Kurikulum Sekolah Dasar: GBPP Bahasa Indonesia. Jakarta: Depdikbud.

Depdiknas. 2003. Kurikulum Berbasis Kompetensi: Kebijaksanaan Umum Pendidikan Dasar dan Menengah. Jakarta: Depdiknas.

Depdiknas, 2004. Kurikulum SD Bidang Studi Bahasa dan Sastra Indonesia. Jakarta: Depdiknas.

Depdiknas, 2007. Kurikulum Nasional: Kurikulum Tingkat Satuan Pendidikan. Jakarta: Depdiknas.

Johnson, J.E, Christie, J.E, dan Yawkey, T.D. 1987, Play and Early Chilhood Development. Glenview IL.b: Scott, Foresman and Company.

Hasanah, M. dan Nurchasanah. 2007. "Pembelajaran Baca-Tulis Permulaan dengan Strategi Permainan". Laporan Penelitian. Malang: Lemlit UM.

Hasanah, M. 2012. "Model Cerita Fiksi Kontemporer Anak-anak untuk Pengembangan Kemahirwacanaan Siswa SD". Jurnal Litera. (1): 95-110.

Nurchasanah. 2002. "Model Interaksi Keluarga dalam Mengembangkan Kemampuan Berbahasa Indonesia Anak Usia Balita". Laporan Penelitian Dasar. Malang: Lembaga Penelitian Universitas Negeri Malang.
Nurchasanah. 2004. "Alternatif Model Pembelajaran Menulis Permulaan". Dalam Jurnal Bahasa dan Seni, hal 10.

Nurchasanah, 2005. "Model Performansi Majalah anak untuk Meningkatkan Kreativitas Berbahasa Klisan Anak Usia Prasekolah". Laporan Penelitian Dasar. Malang: Lembaga Penelitian Universitas Negeri Malang.

Rofi'uddin, A. dan Zuhdi. 1998. Pendidikan Bahasa dan Sastra Indonesia di Kelas Tinggi. Jakarta: Proyek Pendidikan Guru Sekolah Dasar.

Routman, R. 1994. Invitations: Changing as Teachers and Learners K-12. Portsmouth: Heinemann.

Rubin, D. 1995. Teaching Elementary Language Arts: an Integrated Approach. Boston: Allyn and Bacon.

Searfoss, L. \& Redence, W. 1994. Helping Children Learn to Read. Boston: Allyn and Bacon.

Setyosari, Punaji. 2013. Metode Penelitian Pendidikan dan Pengembangan. Jakarta: Kencana.

Spodek, B. dan Saracho, O.N. 1994. Right from the Start: Teaching Children Ages Three to Eight. Boston: Allyn and Bacon.

Sulzby, E., Teale. W.H., \& Kamberelis, G. 1989. Emergent Writing in the Classroom: Home and Schools Connections. In D.S. Strickland \& L.M. Morrow (Eds.) Emerging Literacy: Young Children Learn to Read and Write. Newark, DE: International Reading Association.

Stone, S.J. 1995. Wanted: Advocates for Play in the Primary Grades. Dalam Young Children, September 1995.

Suyanto, K., K. E. dan Adi R. 2005. “Implementasi Penelitian untuk Meningkatkan Kualitas Pembelajaran". Makalah disajikan dalam pelatihan Metodologi PPKP dan PTK di LPM UM, 17 Oktober 2005.

van Horn, J.N., dkk. 1993. Play at the Center of the Early Chilhood Curriculum. New York: MacMillan. 